\title{
Longitudinal Study of Stable Isotope Compositions of Maternal Milk and Implications for the Palaeo-Diet of Infants
}

\author{
Étude longitudinale de la composition isotopique du lait maternel et implications \\ pour la reconstitution de la paléoalimentation infantile
}

\author{
E. Herrscher · G. Goude · L. Metz \\ Reçu le 15 mars 2017; accepté le 14 août 2017 \\ (C) Société d'Anthropologie de Paris et Lavoisier SAS 2017
}

\begin{abstract}
The classic interpretation of stable isotope data from young children in an archaeological context is based on the hypothesis that the nitrogen isotope ratios present in breast milk remain identical throughout the breastfeeding period. This exploratory study assesses the changes in the nitrogen and carbon isotope ratios in maternal milk and in the nails of the mother and child, with the aim to evaluate the impact of variations in the stable isotope ratios in maternal milk on the tissues of children, and consequently on the reconstruction of the palaeo-diet of young children. The results show that the isotopic composition of maternal milk diminishes in relation to the mother's tissues like nails and, by extrapolation, bones. The $\delta^{15} \mathrm{~N}$ values of the milk vary little during the weeks of breastfeeding, but this is not the case for carbon, which varies considerably during the course of breastfeeding and weaning and does not seem to be linked to the mother's diet and/or to the height and weight of the child. The difference between the $\delta^{15} \mathrm{~N}$ values recorded for the mother's and child's nails is less than $2 \%$, which is lower than the values often cited in bioarchaeological literature. In addition, the data from this study does not confirm the hypothesis of a significant increase in heavy isotopes in the nails of newborn babies in relation to those of their mother at childbirth.
\end{abstract}

Keywords Stable isotopes - Carbon · Nitrogen - Maternal milk $\cdot$ Nail $\cdot$ Mother-child

E. Herrscher $(\bowtie) \cdot$ G. Goude $\cdot$ L. Metz

Aix-Marseille Université, CNRS, ministère Culture \& Com,

LAMPEA, F-13094 Aix-en-Provence, France

e-mail : herrscher@mmsh.univ-aix.fr

\section{Metz}

Postdoctoral researcher, Harvard University,

Department of Anthropology,

Peabody Museum of Archaeology and Ethnology, USA
Résumé L'interprétation des données isotopiques des jeunes enfants en contexte archéologique repose sur l'hypothèse que les rapports isotopiques de l'azote du lait maternel restent identiques tout au long de la période d'allaitement. Cette étude exploratoire propose d'appréhender, à partir du suivi longitudinal d'un couple mère-enfant sur 34 semaines, l'évolution des rapports isotopiques de l'azote mais également du carbone du lait maternel et des ongles de la mère et de l'enfant. La finalité est d'évaluer l'incidence des variations des rapports isotopiques du lait maternel sur les tissus des enfants et par conséquent sur la reconstitution de la paléoalimentation des tout-petits. Les résultats montrent que la composition isotopique du lait maternel est appauvrie par rapport aux tissus de la mère, comme les ongles, et par extrapolation à l'os. Les valeurs de $\delta^{15} \mathrm{~N}$ du lait varient peu au cours des tétées, ce qui n'est pas le cas pour le carbone, dont l'importante variation au cours des semaines d'allaitement et de sevrage ne semble pas être en lien avec l'alimentation de la mère et/ou l'évolution staturopondérale de l'enfant. L'écart des valeurs de $\delta^{15} \mathrm{~N}$, enregistré entre les ongles de l'enfant et de la mère, est inférieur à $2 \%$, donc en dessous des valeurs souvent considérées dans la littérature bioarchéologique. De plus, les données de cette étude ne confirment pas l'hypothèse d'un enrichissement significatif en isotopes lourds des ongles des nouveau-nés relativement à ceux de leur mère à la naissance.

Mots clés Isotopes stables $\cdot$ Carbone $\cdot$ Azote $\cdot$ Lait maternel $\cdot$ Ongle $\cdot$ Mère-enfant

\section{Introduction}

Biogeochemical methods like dose rate of stable isotopes and trace elements have been developed considerably from the beginning of 1990s, leading to new approaches for recording breastfeeding and weaning in past populations (recent 
overviews [1-5]). These methods provide direct markers to assess the consumption of breast milk (stable isotopes of nitrogen and oxygen) and estimate the type of weaning food (carbon and sulphur isotopes, trace elements of strontium and barium). When these approaches have been applied to individuals of known age at death, they produce an estimation of the duration of breastfeeding and of the weaning age in populations represented only by archaeological remains for inter and intra-individual analyses [6-11].

The marker that has been most frequently considered was the isotopic ratio of nitrogen measured in the organic fraction of bones and teeth (collagen). This marker has been used in ecology for a long time to track the different trophic levels in a food chain, and mainly takes into account the type of protein in the food. Studies carried out on living organisms have shown that the $\delta^{15} \mathrm{~N}$ values increase from the primary producers (plants) through the different successive trophic levels (herbivores, omnivores and carnivores) [1214]. In each link of the food chain, the tissues of organisms become richer in heavy isotopes $\left({ }^{15} \mathrm{~N}\right)$, as a consequence of "isotopic fractionation", a process affecting the relative abundance of isotopes according to physiological factors, the main one being preferential excretion of the light isotope $\left({ }^{14} \mathrm{~N}\right)$ in urine and faeces $[15,16]$. Enrichment ranges from 3 to $6 \%$ between food and some tissues in adults, but from 3 to $5 \%$ in the collagen of two successive trophic levels $[14,16,17]$.

Nutritional experiments on breastfed and non-breastfed mother-child pairs showed that there was a gradual enrichment, from 1.7 to $2.8 \%$, in ${ }^{15} \mathrm{~N}$ in the tissues of breastfed children in relation to their mothers, from 10 th to 12 th postnatal week $[6,18]$. This rate of enrichment are correlated with the duration of maternal milk intake, then followed by a relatively rapid decrease in ${ }^{15} \mathrm{~N}$, corresponding to a change in the diet that indicates the introduction of weaning food [18]. During the course of the breastfeeding and weaning process, the $\delta^{15} \mathrm{~N}$ values in the infants' tissue thus form a "bell-curve", where the top corresponds to the end of exclusive breastfeeding [1]. Fuller and collaborators [18] have also showed an increase in ${ }^{13} \mathrm{C}$ in the tissues of breastfed children, and recommended its use as a proxy to monitor the consumption of maternal milk.

Until now, the interpretation of the $\delta^{15} \mathrm{~N}$ values in archaeological contexts were based on the a priori hypothesis of no fractionation between the mother's bone collagen and the maternal milk $[18,19]$. Yet, according to the available data from animals, a difference in ${ }^{15} \mathrm{~N}$ of -0.5 to $-2.3 \%$ has been observed between the collagen and the milk of the organism synthesizing it [4]. Recently, similar results were observed in women by a French team working on the Inserm-EDEN cohort, with mean $\delta^{15} \mathrm{~N}$ values for maternal milk about $2.5 \%$ lower than those measured in the mothers' hair at childbirth $[20,21]$. However, until now, no $\delta^{13} \mathrm{C}$ data have been published. Another result of the a priori hypotheses, which is used to interpret isotopic data from young children in archaeological contexts, is that the $\delta^{15} \mathrm{~N}$ maternal milk values remain identical throughout the breastfeeding period. Yet we know that the nutritional and immunological characteristics of maternal milk change during the course of breastfeeding, depending on the child's age, or sex [22,23]. To our knowledge, no study has yet investigated changes in the isotopic values of human breast milk during the course of breastfeeding.

This exploratory study assesses changes in the nitrogen and carbon isotopic ratios of maternal milk during breastfeeding and weaning in a mother-infant pair over a period of 34 weeks, using longitudinal tracking. It also measures the isotopic ratios at different moments in the same day and compares them to the isotopic ratios of the nails of the mother and infant. The aims are (i) to analyse the isotopic composition of the milk in relation to the time of feeding and the child's growth and (ii) to characterize the isotopic fractionation for nitrogen and carbon in the milk, the mother and the infant at different times. The purpose of this exploratory research is to assess the impact of variations in the isotopic ratios of the maternal milk on the child's tissues, and consequently, on the reconstruction of the palaeo-diet of young children. In addition, while some authors explain the enrichment in ${ }^{15} \mathrm{~N}$ in breastfed children as the result of significant metabolic activity from birth to 2 years of age [21,24,25], this exploratory study will attempt to reconsider the possible influence of growth on the modification of $\delta^{15} \mathrm{~N}$ values during breastfeeding.

\section{Materials}

This study was carried out with a mother-infant pair from 4th to 34th week of breastfeeding after birth (November 2013 to June 2014). ${ }^{1}$ The baby was exclusively breastfed until 12th week, then mainly breastfed until food diversification from 21 st week. The dietary characteristics of the mother were observed along with the baby's first substitute foods and its stature and weight. The mother's diet consisted mainly of terrestrial type $\mathrm{C}_{3}$ food (meat, eggs, vegetables, cereals; very few industrial/processed products and occasionally fish). Type $\mathrm{C}_{4}$ plants, such as millet or sorghum, were not part of the daily diet. For the infant, the first solid foods were introduced from the 4th month, as a complement to breastfeeding. These consisted of vegetable purees until 6 months, then type $C_{3}$ plants, meat, fish and eggs (nonindustrial/processed).

\footnotetext{
${ }^{1}$ The child was born at full term. Neither the child nor the mother presented any pathology that could have led to nutritional or metabolic problems.
} 
The introduction of animal proteins at 6 months was concomitant with reducing breast milk feeds to twice a day. Milk samples were taken about twice a month and several times throughout the day for some of them $(n=31)$. In addition, samples were taken from fingernail clippings from both mother and infant ( $n=7$; between November 2013 and June 2014). The time required for the incorporation of new nutrients into the ends of the nails has been estimated from physiological growth data. In adults, fingernails grow by about $1.9-4.4 \mathrm{~mm} / \mathrm{month}$ and it takes about 6 months for a whole nail to grow back entirely [26]. Nail growth is faster in children, generally 2-3 months [27]. Given the average size of nails up until the age of 9 months $^{2}$ (between 3 and $5 \mathrm{~mm}$ ), it would take about 6 weeks for a baby's nail to grow back entirely. On the other hand, work carried out with motherinfant pairs showed that it took at least 12 weeks for the maternal milk diet to be recorded in the infant's tissue [18]. Thus, in our case, the baby's fingernail clippings taken at 7 weeks of age correspond to tissues incorporating in utero information, those taken at 11 and 21 weeks correspond to a formation period of exclusive breastfeeding, whereas those taken at 21 weeks and 29 weeks correspond to a formation period when breastfeeding is supplemented by vegetable purees or other foods. For the mother, the fingernail clippings taken at 5 and 11 weeks after childbirth correspond to a food signal during pregnancy, whereas those taken at 38 weeks correspond to a food signal during the $3 \mathrm{rd}$ month of breastfeeding.

\section{Methods}

The stable carbon $\left(\delta^{13} \mathrm{C}\right)$ and nitrogen $\left(\delta^{15} \mathrm{~N}\right)$ isotope ratios measured in proteins in body tissues provide information on diet, environment and certain physiological aspects, particularly those related to growth [28-31]. The isotopic ratios of tissue such as hair, nails, bone and teeth are linked to those of food eaten over the course of the past weeks or years, depending on the speed of growth and the renewal of proteins in the sample in question (hair $>$ nail $>$ bone-tooth). Isotopic fractionation occurs in favour of the heaviest element $\left({ }^{13} \mathrm{C}\right.$, $\left.{ }^{15} \mathrm{~N}\right)$, leading to an enrichment of the tissue $\left(\pi \delta^{13} \mathrm{C}, \pi \delta^{15} \mathrm{~N}\right)$ in relation to the diet, which differs depending on tissues. Work carried out on hair keratin and bone collagen from live adults showed an average enrichment in heavy isotopes in the proteins of these two tissues of $1.4 \%$ for carbon and $0.9 \%$ o for nitrogen and an average ${ }^{15} \mathrm{~N}$ enrichment of $0.7 \%$ in hair and nails [32]. These enrichments were taken into consideration to estimate the isotopic ratios of the bone of the mother-child pair from data obtained from the nails.

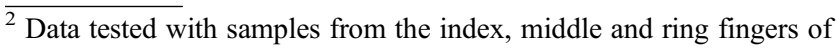
several children.
}

Bone turnover in the child was estimated from present-day data concerning the turnover of human tissue. The turnover rate of compact bone is estimated at $300 \%$ on average during the first months of life and at about $100 \%$ at one year of age [33]. Based on this, our postulates are: (1) bone potentially reflects the isotopic composition of maternal milk after 3 months ${ }^{3}$; and (2) the enrichment in ${ }^{15} \mathrm{~N}$ between the maternal milk and the bone collagen of the child would require the same lapse of time.

The nail clippings were first cleaned in water and in an ultrasound acetone bath, then lyophilised to eliminate any residual humidity. The maternal milk has been taken directly from the mother's breast in a sterile glass vial, and then frozen and lyophilised. The isotopic measurements were taken on lyophilized samples using an elementary Europa Scientific analyser combined with a Europa Scientific 20-20 isotopic mass spectrometer (Iso-Analytical Ltd. Crewe, England). The measurements were taken using internal standards calibrated from international IAEA standards.

Only non-parametric tests were used, such as the KruskalWallis and Mann-Whitney tests, which were performed with Statistica (CV.9).

\section{Results}

Between the 4th and the 34th week, the isotopic ratios of the maternal milk range from -27.5 to $-24.9 \%$ or carbon and from 7.5 to $8.6 \%$ for nitrogen (respectively (mean $\pm 1 \sigma$ ): $-26.3 \pm 0.7 \%$; $8.0 \pm 0.3 \%$ o $n=31$; Table 1 ). No tendency appears between the different milk samples and the breastfeeding periods (through the day and during the months) for nitrogen isotopic values. On the other hand, the carbon isotopic composition of the milk is more variable $\left(\Delta^{13} \mathrm{C}=2.6 \%\right.$ ). The milk samples between the 4 th and the 9th week present $\delta^{13} \mathrm{C}$ values below $-25.9 \%$, whereas those taken between the 11 th and 27 th week show values ranging from -25.9 to $-25.1 \%$ (Fig. 1). The values from the 28 th to the 34 th week range from -26.9 to $-24.9 \%$. The differences are significant between these three periods (ANOVA Kruskal-Wallis: $\left.p\left(\delta^{13} \mathrm{C}\right)<0.001\right)$ and significant between the first period (from 4th to the 9th week) and the second period (from the 11 th to the 27 th week) (U-Mann-Whitney Test: $\left.p\left(\delta^{13} \mathrm{C}\right)<0.001\right)$. During the same day, carbon and nitrogen isotope values can vary by up to $1 \%$ but no tendency was observed at the time of feeding (Fig. 2). No correlation appeared between the isotopic values of the maternal milk and the infant's weight and height data. However the few BMI data calculated showed variations between the 11th

\footnotetext{
$\overline{3}$ This estimation is proposed according to the nail data recorded in this study. However we do not have a full understanding of the different turnover of nail and bone during this period of infancy.
} 


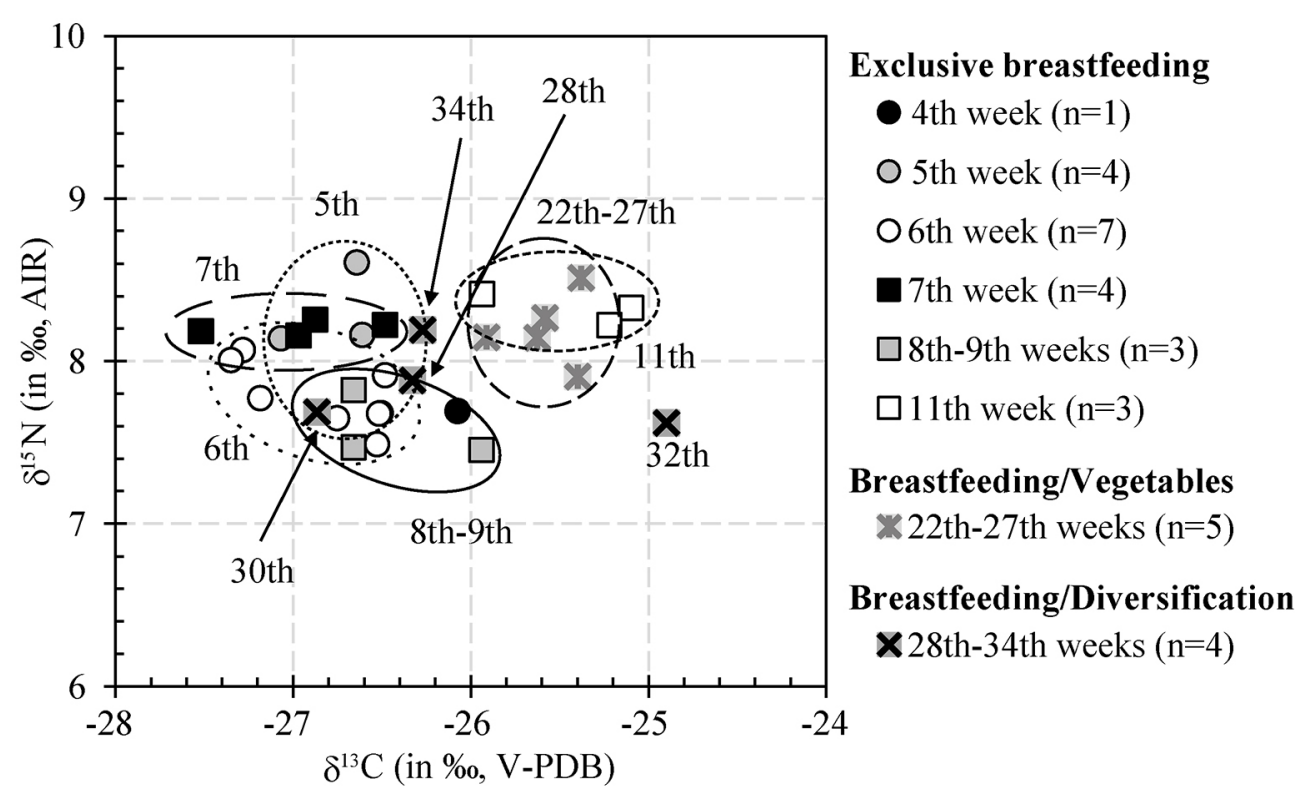

Fig. 1 Carbon and nitrogen isotopic ratios according to the different maternal milk samples (the ellipses delineate the variation of data for each week's study) / Rapports isotopiques du carbone et de l'azote des prélèvements de lait maternel au cours de la période d'allaitement (les ellipses délimitent la variation des données pour chaque semaine étudiée)

and the 28th week, which matches the increase in the $\delta^{13} \mathrm{C}$ values of maternal milk.

Over the full duration of the study, the $\delta^{13} \mathrm{C}$ values for the mother's nails range from -21.5 to $-21.0 \%$ and the $\delta^{15} \mathrm{~N}$ values from 9.4 to $10.1 \%$, whereas the child's nails vary between -21.5 and $-21.1 \%$ and between 9.9 and $12.5 \%$ (Table 2).

In comparison to the isotope ratios for the mother's milk, the isotope ratios for the mother and the child's nails are enriched in heavier isotopes by $4.8-5.2 \%$ o for carbon whereas the ${ }^{15} \mathrm{~N}$ enrichment between maternal milk and nails ranges from 1.4 to $2.1 \%$ or the mother and from 4.8 to $5.2 \%$ for the child (Tables 1, 2, Fig. 3).

\section{Discussion}

\section{Maternal milk}

Given the changes in the isotopic carbon ratios of maternal milk during the course of breastfeeding, the dietary investigation conducted on the mother did not show any significant modification in food intake between 11th and 27th week to account for the variations observed. The consumption of aquatic, and particularly marine, resources can lead to an increase in the $\delta^{13} \mathrm{C}$ values in consumers' tissues, in relation to the intake of land resources [34]. In this case, marine resources were only consumed occasionally, and without regularity, and therefore cannot explain these results. Could these variations in the isotopic values of the maternal milk follow the BMI modification of the child and the first introduction of solid food (vegetables)? We do not have enough data to back up such an assumption. However, this isotopic variability could result from differences in isotopic fractionation in response to as yet insufficiently known physiological constraints, such as differences in the use of amino acids during milk synthesis in the mammary gland [35], adaptation of milk composition to the infant's needs [23] and physiological stress of the mother (e.g. short nights, tiredness) [36-38].

\section{Nails of the mother and the child}

Given that it takes about 24 weeks for new nutrients to be incorporated into maternal nail tissue and about 12 weeks in the case of infant nail tissue [18], the changes in the isotopic values for the mother and the child during the last prenatal and the first post-natal weeks were extrapolated and reported in Table 2 and Fig. 3.

In this way, and subtracting the time of incorporation for the mother and the baby, we note, firstly, that for the period close to birth, the isotopic values, whether for carbon or nitrogen, shows mother-infant differences of less than $0.5 \%$ (Fig. 3), confirming the earlier work on mother-infant pairs $[6,18]$. However, these values are still below those obtained from hair from mother-infant pairs in the EDEN cohort, i.e. for nitrogen, which show a significant average difference of $+0.9 \%$, as opposed to $+0.4 \%$ or forbon [20]. The differences between our data and the study conducted by De Luca and collaborators [20] could be related to (i) the 

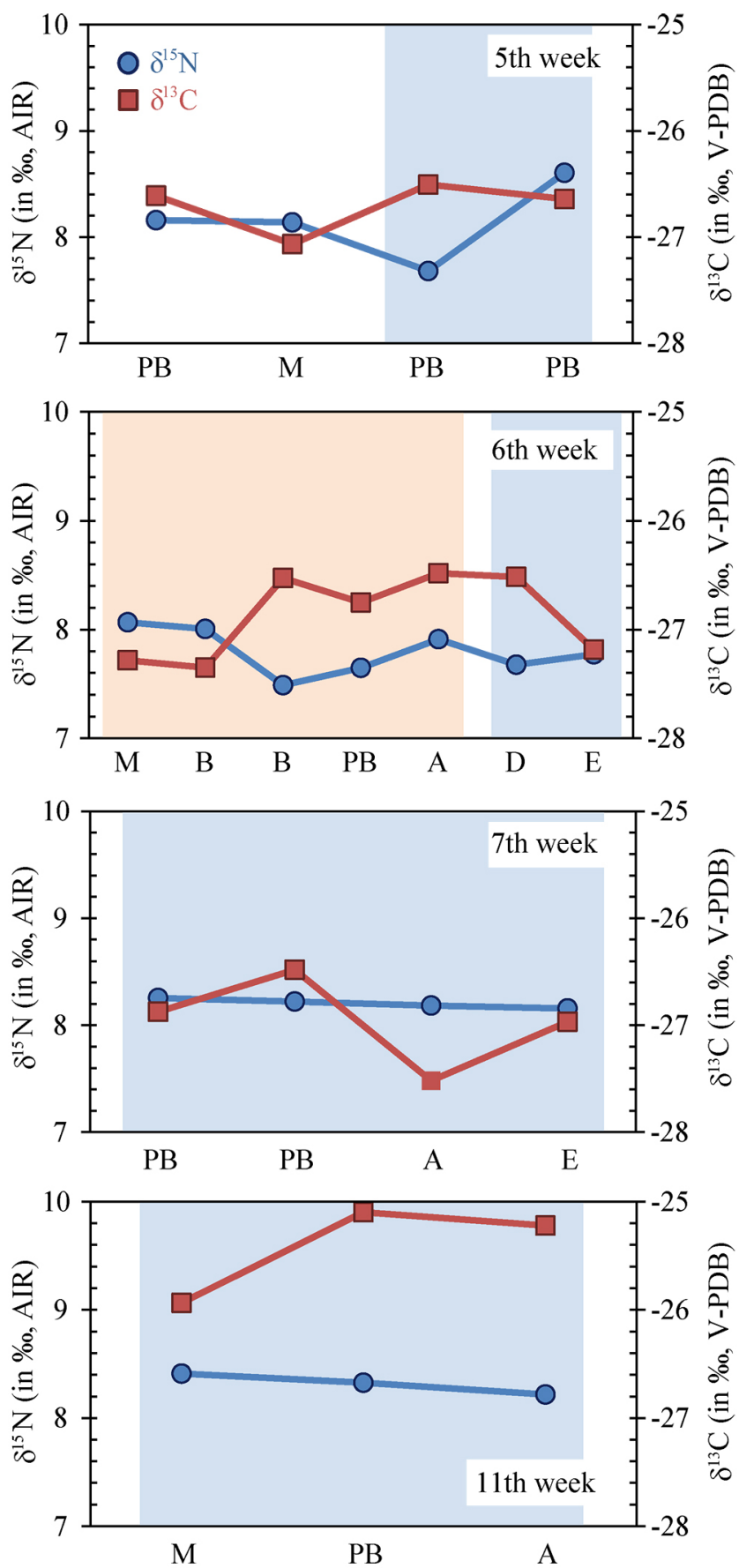

Fig. 2 Maternal milk carbon and nitrogen isotopic ratios according to the different suckling times shaded areas show suckling moments during the same day; $M$ : Morning; $B$ : Breakfast; $P B$ : Post-Breakfast; $A$ : Afternoon; D: Dinner; E: Evening) / Rapports isotopiques du carbone et de l'azote des prélèvements de lait maternel en fonction des tétées (les zones colorées indiquent les prélèvements réalisés sur la même journée ; $M$ : Matin; $B$ : Petit déjeuner ; PB : Post-petit déjeuner ; $A$ : Après-midi ; $D$ : Diner ; E : Soirée). large sample size $(n>200)$ including the mothers' isotopic variability resulting from varied diets and (ii) the tissue analysed (hair), where the timing of nutrient incorporation is not the same as for nails. According to the authors, the isotope difference in mother-infant pairs showed the impact of in utero protein metabolism on the tissues of the newborn babies from the time of birth onwards.

Secondly, the slight enrichment in ${ }^{13} \mathrm{C}$ between the child's and the mother's tissues during breastfeeding $\left(\Delta{ }^{13} \mathrm{C}_{\text {Child-Mother }}<0.5 \%\right.$ ) is less marked than previously observed by Fuller and collaborators, which was about 1\% [18]. In contrast, while the nitrogen isotope ratios of the mother's nails concur at around 9.7\%, the infant's nails show higher $\delta^{15} \mathrm{~N}$ values than those of the mother from the extrapolated 9th week $\left(\Delta^{15} \mathrm{~N}_{\text {Child-Mother }} \approx 2.0 \%\right.$ ) and clearly higher values during the extrapolated 17 th week $\left(\Delta^{15} \mathrm{~N}_{\text {Child-Mother }}\right.$ $\approx 2.8 \%$ ). These results show that the tissues sampled from the child's nails before the 11th post-natal week, corresponding more or less to the birth, had not yet recorded any dietary modification linked to breastfeeding, whereas those formed after the 21th post-natal week, at least, are significantly enriched in ${ }^{15} \mathrm{~N}$, corresponding to the breast milk diet (Fig. 3). The enrichment in ${ }^{15} \mathrm{~N}$ in the child's nails thus appears to be consistent with that observed in the first studies on this topic, with identical values (between 1.7 and 2.8\% [6,18]).

In relation to the different questions raised at the beginning of this paper, this exploratory study does not support the hypothesis of significant enrichment in heavy isotopes of the nails of newborn babies in comparison to those of their mother at childbirth.

\section{Contributions of these results to studies on palaeo-diets}

This study addresses two key points for reconstructing past dietary behaviour: (i) the changes in bone isotope ratios and (ii) the isotope spacing between diet and tissue (Fig. 3).

By applying the isotopic enrichment between nails and bone of $+1.4 \%$ in ${ }^{13} \mathrm{C}$ and $+0.2 \%$ in ${ }^{15} \mathrm{~N}$ [32], it is possible to extrapolate the data obtained from nails to the values expected for bone samples, which are the main remains found in archaeological contexts (Fig. 3). The tendencies remain identical, with a significant increase in $\delta^{15} \mathrm{~N}$ values between the mother and the child, whereas the $\delta^{13} \mathrm{C}$ values remain similar. The difference of less than $2 \%$ recorded for nitrogen isotope ratios between the child and its mother was below the values often considered in the bioarchaeological literature (3-5\% corresponding to a trophic level), which raised the question of the validity of approaches based on comparisons of $\delta^{15} \mathrm{~N}$ values between female individuals and children of unknown kinship $[9,19]$. Indeed, the isotopic differences between mother and infant are too slight to be observed in archaeological bones. The main point is that as we (practically) never have access to mother-infant pairs, 
Table 1 Elemental and isotopic compositions of maternal milk samples / Données élémentaires et isotopiques des prélèvements de lait maternel

\begin{tabular}{|c|c|c|c|c|c|c|c|c|c|c|c|}
\hline \multirow{2}{*}{$\begin{array}{l}\text { Lab- } \\
\text { Code }\end{array}$} & \multirow{2}{*}{$\begin{array}{l}\text { Sampling } \\
\text { date }\end{array}$} & \multirow{2}{*}{$\begin{array}{l}\text { Postna- } \\
\text { tal } \\
\text { week }\end{array}$} & \multirow{2}{*}{$\begin{array}{l}\text { Suckling } \\
\text { time }\end{array}$} & \multicolumn{3}{|l|}{ Child } & \multirow[t]{2}{*}{$\% \mathrm{C}$} & \multirow[t]{2}{*}{$\% \mathrm{~N}$} & \multirow[t]{2}{*}{$\mathbf{C} / \mathbf{N}$} & \multirow[t]{2}{*}{$\delta^{13} C_{V-P D B}$} & \multirow[t]{2}{*}{$\delta^{15} N_{\text {AIR }}$} \\
\hline & & & & Food & $\begin{array}{l}\text { Weight } \\
\text { (g) }\end{array}$ & $\begin{array}{l}\text { Stature } \\
(\mathrm{cm})\end{array}$ & & & & & \\
\hline Lal & $15 / 11 / 2013$ & 4 & After lunch & $\mathrm{AE}$ & & & 52.1 & 1.6 & 36.8 & -26.1 & 7.7 \\
\hline $\mathrm{La} 2$ & $18 / 11 / 2013$ & 5 & After lunch & $\mathrm{AE}$ & & & 51.9 & 2.0 & 29.7 & -26.5 & 7.7 \\
\hline $\mathrm{La} 3$ & $21 / 11 / 2013$ & 5 & After lunch & $\mathrm{AE}$ & & & 58.3 & 1.6 & 41.6 & -26.6 & 8.6 \\
\hline La4 & $22 / 11 / 2013$ & 5 & $\begin{array}{l}\text { After } \\
\text { breakfast }\end{array}$ & $\mathrm{AE}$ & & & 49.8 & 1.8 & 32.6 & -26.6 & 8.2 \\
\hline La5 & $22 / 11 / 2013$ & 5 & $\begin{array}{l}\text { End } \\
\text { of morning }\end{array}$ & $\mathrm{AE}$ & & & 55.8 & 1.9 & 34.8 & -27.1 & 8.1 \\
\hline $\mathrm{La} 6$ & $27 / 11 / 2013$ & 6 & Lunch & $\mathrm{AE}$ & 4500 & 55 & 51.1 & 1.7 & 35.0 & -26.5 & 7.5 \\
\hline $\mathrm{La} 7$ & $27 / 11 / 2013$ & 6 & After lunch & $\mathrm{AE}$ & 4500 & 55 & 54.8 & 1.7 & 36.7 & -26.8 & 7.6 \\
\hline $\mathrm{La} 8$ & $27 / 11 / 2013$ & 6 & Afternoon & $\mathrm{AE}$ & 4500 & 55 & 53.5 & 1.8 & 35.3 & -26.5 & 7.9 \\
\hline La9 & $27 / 11 / 2013$ & 6 & Dinner & $\mathrm{AE}$ & 4500 & 55 & 55.2 & 1.8 & 36.1 & -26.5 & 7.7 \\
\hline La10 & $27 / 11 / 2013$ & 6 & Evening & $\mathrm{AE}$ & 4500 & 55 & 59.4 & 1.6 & 42.0 & -27.2 & 7.8 \\
\hline La11 & $28 / 11 / 2013$ & 6 & Morning & $\mathrm{AE}$ & 4500 & 55 & 55.0 & 1.8 & 36.3 & -27.3 & 8.1 \\
\hline La12 & $28 / 11 / 2013$ & 6 & Lunch & $\mathrm{AE}$ & 4500 & 55 & 56.0 & 1.5 & 42.6 & -27.3 & 8.0 \\
\hline La13 & $06 / 12 / 2013$ & 7 & $\begin{array}{l}\text { After } \\
\text { breakfast }\end{array}$ & $\mathrm{AE}$ & & & 53.4 & 1.4 & 45.4 & -26.9 & 8.3 \\
\hline La14 & $06 / 12 / 2013$ & 7 & After lunch & $\mathrm{AE}$ & & & 44.4 & 1.9 & 27.8 & -26.5 & 8.2 \\
\hline La15 & $06 / 12 / 2013$ & 7 & Afternoon & $\mathrm{AE}$ & & & 54.7 & 1.5 & 43.8 & -27.5 & 8.2 \\
\hline La16 & $06 / 12 / 2013$ & 7 & Evening & $\mathrm{AE}$ & & & 45.8 & 1.6 & 33.1 & -27.0 & 8.2 \\
\hline La17 & $11 / 12 / 2013$ & 8 & $\begin{array}{l}\text { End } \\
\text { of morning }\end{array}$ & $\mathrm{AE}$ & & & 51.2 & 1.5 & 38.4 & -26.7 & 7.5 \\
\hline La18 & $13 / 12 / 2013$ & 8 & $\begin{array}{l}\text { End } \\
\text { of morning }\end{array}$ & $\mathrm{AE}$ & & & 46.5 & 1.6 & 34.6 & -25.9 & 7.5 \\
\hline La19 & $16 / 12 / 2013$ & 9 & $\begin{array}{l}\text { End } \\
\text { of morning }\end{array}$ & $\mathrm{AE}$ & & & 50.5 & 1.4 & 41.9 & -26.7 & 7.8 \\
\hline La20 & $01 / 01 / 2014$ & 11 & $\begin{array}{l}\text { End } \\
\text { of morning }\end{array}$ & $\mathrm{AE}$ & 5470 & 57 & 56.2 & 1.3 & 50.6 & -25.9 & 8.4 \\
\hline $\mathrm{La} 21$ & $01 / 01 / 2014$ & 11 & After lunch & $\mathrm{AE}$ & 5470 & 57 & 47.9 & 1.9 & 29.5 & -25.1 & 8.3 \\
\hline $\mathrm{La} 22$ & $01 / 01 / 2014$ & 11 & Afternoon & $\mathrm{AE}$ & 5470 & 57 & 45.5 & 1.9 & 28.1 & -25.2 & 8.2 \\
\hline $\mathrm{La} 23$ & $20 / 03 / 2014$ & 22 & Lunch & $\mathrm{Apu}$ & & & 43.1 & 1.8 & 28.4 & -25.4 & 8.5 \\
\hline $\mathrm{La} 24$ & $27 / 03 / 2014$ & 23 & $\begin{array}{l}\text { End } \\
\text { of morning }\end{array}$ & Apu & & & 55.1 & 1.2 & 51.5 & -25.9 & 8.1 \\
\hline $\mathrm{La} 25$ & $03 / 04 / 2014$ & 24 & After lunch & Apu & 6600 & 65.5 & 49.5 & 1.6 & 35.9 & -25.6 & 8.1 \\
\hline La26 & $10 / 04 / 2014$ & 25 & After lunch & Apu & & & 51.2 & 1.8 & 32.3 & -25.6 & 8.3 \\
\hline $\mathrm{La} 27$ & $24 / 04 / 2014$ & 27 & $\begin{array}{l}\text { After } \\
\text { breakfast }\end{array}$ & Apu & & & 54.9 & 1.6 & 39.5 & -25.4 & 7.9 \\
\hline $\mathrm{La} 28$ & $01 / 05 / 2014$ & 28 & Dinner & ADiv & 7000 & 66 & 57.4 & 1.6 & 41.6 & -26.3 & 7.9 \\
\hline La29 & $15 / 05 / 2014$ & 30 & Afternoon & ADiv & & & 55.1 & 1.2 & 52.4 & -26.9 & 7.7 \\
\hline La30 & $29 / 05 / 2014$ & 32 & & ADiv & & & 51.5 & 1.7 & 35.5 & -24.9 & 7.6 \\
\hline La31 & $12 / 06 / 2014$ & 34 & & ADiv & & & 53.5 & 1.5 & 40.1 & -26.3 & 8.2 \\
\hline
\end{tabular}

$A E$ : Breastfeeding only; Apu: Breastfeeding and mashed vegetables; ADiv: Breastfeeding and food diversification including vegetables/meat/fish 

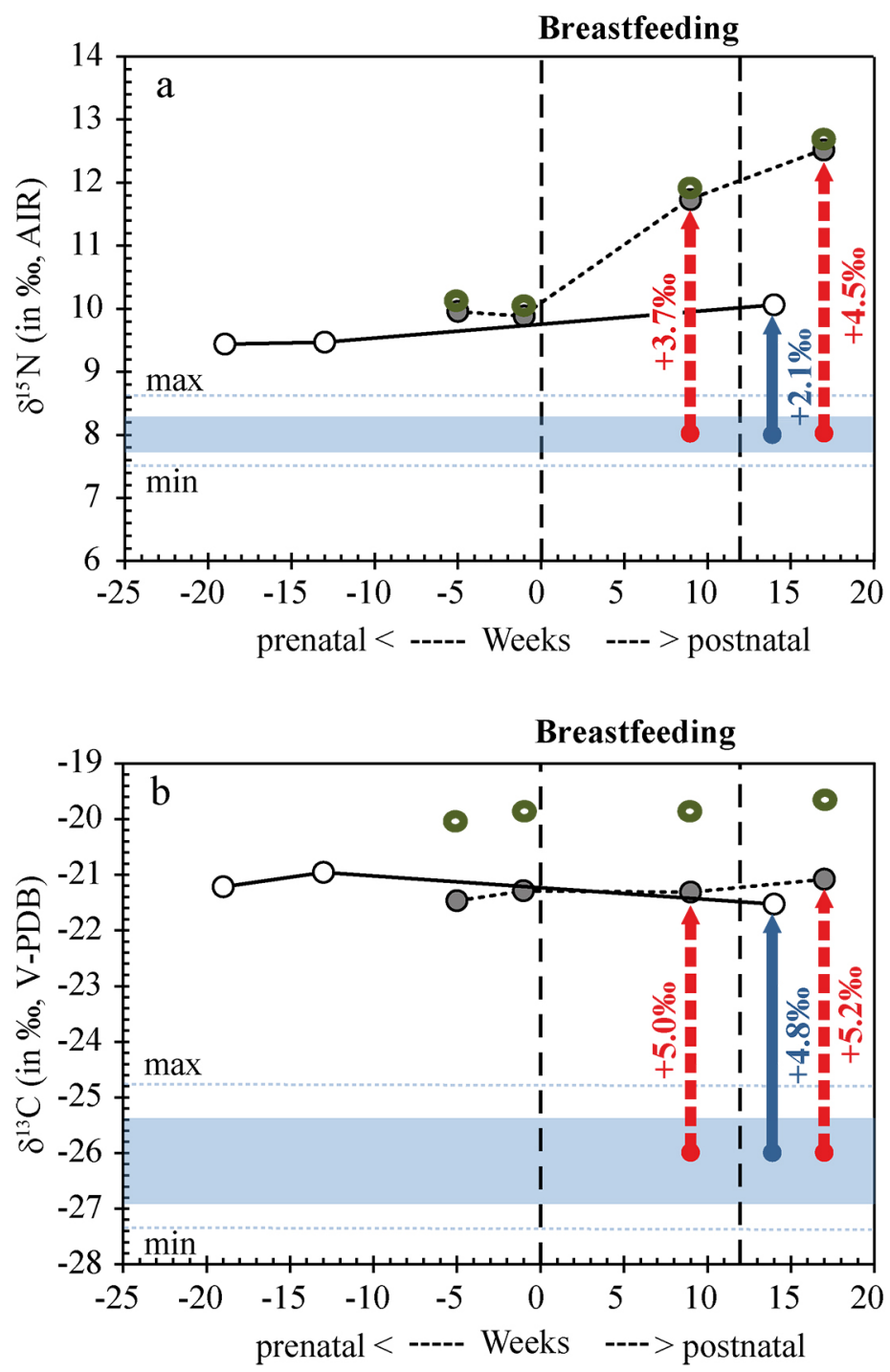

Nail tissues

-o- Child

-o- Mother

Maternal milk

mean $\pm 1 \sigma$

\section{Post-natal mean enrichment in ${ }^{15} \mathrm{~N} /{ }^{13} \mathrm{C}$ \\ Maternal milk \\ -Mother's nail \\ Maternal milk \\ -Child's nail}

\section{Theoretical isotope enrichment}

$\Delta^{15} \mathrm{~N}_{\text {bone-nail }}=+0.2 \%$

$\Delta^{13} \mathrm{C}_{\text {bone-nail }}=+1.4 \%$

- Expected

Child bone value

Fig. 3 Carbon (a) and nitrogen (b) isotopic ratios in mother's and child's nails before and after the birth; estimated data for child's bones (the grey rectangle shows the mean, standard deviation, maximum and minimum for the 31 maternal milk samples; the arrows show the isotopic fractionation recorded between maternal milk and the child's and mother's nails) / Rapports isotopiques de l'azote (a) et du carbone (b) des ongles du couple mère-enfant avant et après la naissance et estimation des valeurs isotopiques pour un prélèvement osseux chez l'enfant (le rectangle grisé indique la moyenne, l'écart-type ainsi que le maximum et le minimum pour les 31 prélèvements de lait maternel : les flèches indiquent le fractionnement isotopique enregistré entre le lait maternel et l'ongle de l'enfant et de la mère).

inter-individual isotope variability between females and infants should not be considered as pinpointing the dietary status of a child (breastfed/weaned).

Over the longitudinal analysis, the nitrogen isotope ratios of maternal milk become depleted in comparison to the mother's nails (Fig. 3), which confirmed the most recently recorded data from animals and humans $[4,20,21]$. The nitrogen isotope spacing of $\approx 2.1 \%$ o between maternal milk and the mother's nails was slightly less than that reported by de Luca and collaborators, of about $2.5 \%$ for hair [21]. On the other hand, our data are the first to document the carbon isotope spacing between breast milk and maternal tissue, of around 5.1\%o. Considering the theoretical isotope fractionation between diet and bone, of $+5 \%$ in ${ }^{13} \mathrm{C}$ and $+3-5 \%$ in ${ }^{15} \mathrm{~N}[14,39]$, the consumption of maternal milk can be considered as one of the best potential explanations of the increase in the child's expected bone isotope ratios. However, we are aware that other factors, such as growth, diet quality and use of non-protein nitrogen sources via their synthesis in the intestinal microbiome, also play a role in bone composition and turnover $[4,20,40-42]$.

To summarise, it appears from the modern data obtained in this study that the pattern of isotopic values recorded in children's tissues during the course of breastfeeding and 
Table 2 Elemental and isotopic compositions of the mother's and child's nails / Données élémentaires et isotopiques des ongles du couple mère-enfant

\begin{tabular}{|c|c|c|c|c|c|c|c|c|c|c|c|c|}
\hline \multirow{2}{*}{$\begin{array}{l}\text { Lab- } \\
\text { Code }\end{array}$} & \multirow{2}{*}{$\begin{array}{l}\text { Sampling } \\
\text { date }\end{array}$} & \multirow{2}{*}{$\begin{array}{l}\text { Indivi- } \\
\text { dual }\end{array}$} & \multirow{2}{*}{$\begin{array}{l}\text { Post- } \\
\text { natal } \\
\text { week }\end{array}$} & \multirow{2}{*}{$\begin{array}{l}\text { Extrapo- } \\
\text { lated } \\
\text { week }\end{array}$} & \multicolumn{3}{|l|}{ Child } & \multirow[t]{2}{*}{$\% \mathrm{C}$} & \multirow[t]{2}{*}{$\% \mathbf{N}$} & \multirow[t]{2}{*}{$\mathbf{C} / \mathbf{N}$} & \multirow{2}{*}{$\begin{array}{l}\delta^{13} C_{V-} \\
\text { PDB }\end{array}$} & \multirow[t]{2}{*}{$\delta^{15} \mathbf{N}_{\mathrm{AIR}}$} \\
\hline & & & & & Food & $\begin{array}{l}\text { Weight } \\
\text { (g) }\end{array}$ & $\begin{array}{l}\text { Stature } \\
(\mathrm{cm})\end{array}$ & & & & & \\
\hline On1 & $22 / 11 / 2013$ & Mother & 5 & -19 & $\mathrm{AE}$ & & & 43.4 & 14.0 & 3.6 & -21.2 & 9.4 \\
\hline On2 & $09 / 12 / 2013$ & Child & 7 & -5 & $\mathrm{AE}$ & & & 50.1 & 14.4 & 4.0 & -21.5 & 10.0 \\
\hline On3 & $31 / 12 / 2013$ & Child & 11 & -1 & $\mathrm{AE}$ & 5470 & 57 & 39.9 & 11.5 & 4.0 & -21.3 & 9.9 \\
\hline On4 & $01 / 01 / 2014$ & Mother & 11 & -13 & $\mathrm{AE}$ & & & 43.8 & 14.6 & 3.5 & -21.0 & 9.5 \\
\hline On5 & $13 / 03 / 2014$ & Child & 21 & 9 & Apu & 6200 & 64 & 40.6 & 11.8 & 4.0 & -21.3 & 11.7 \\
\hline On6 & $05 / 05 / 2014$ & Child & 29 & 17 & ADiv & & & 47.2 & 13.9 & 3.9 & -21.1 & 12.5 \\
\hline On7 & $01 / 07 / 2014$ & Mother & 38 & 14 & ADiv & & & 44.5 & 14.4 & 3.6 & -21.5 & 10.1 \\
\hline
\end{tabular}

AE: Breastfeeding only; Apu: Breastfeeding and vegetables mash; ADiv: Breastfeeding and food diversification including vegetables/ meat/fish

weaning processes is more complex than previously thought. Nitrogen isotope ratios are still a relevant proxy for tracking the consumption, decrease or stopping of maternal milk, whereas $\delta^{13} \mathrm{C}$ does not seem to be a relevant proxy, which confirms previously obtained results [11,43]. These results must be taken into consideration when using archaeological stable isotope bone data to detect ancient breastfeeding and weaning patterns. The direct comparison between female and infant bone values in this case is not relevant to estimate breastfeeding and weaning in infants because of the lower values of maternal milk and the inter-variability of females within an archaeological population. In addition, in recent years, infant palaeodietary studies have been much improved by using micro-sampling strategies and multi-proxy approaches [44,45]. Even with such improvements based on intra-individual analysis, our exploratory study argues in favour of considering the isotopic variability of maternal milk (=infant diet; mainly for $\delta^{13} \mathrm{C}$ ) when interpreting "micro-event" variations in infant tissues, since maternal milk can be influenced by the mother's physiological stress and cultural behaviour [35-37].

\section{Conclusion}

This longitudinal analysis of maternal milk over 34 weeks showed that the isotopic composition of maternal milk becomes depleted in relation to the mother's tissues, such as nails and, by extrapolation, to bone. It also showed a certain stability in nitrogen isotope values $\left(\Delta^{15} \mathrm{~N} \approx 1 \%\right.$ ) during the course of breastfeeding and weaning, as well as during the course of successive feeds in the same day. On the other hand, although the carbon isotope values of milk can also show slight differences between feeds during the same day, these differences can be much higher during the breastfeeding and weaning periods $\left(\Delta^{13} \mathrm{C} \approx 2.5 \%\right.$ ). No tangible evidence from the investigation into the mother's diet can explain these differences, which could be due to a physiological problem linked to lactation or maternal stress. Additional analyses are required to confirm the recurrence of this observation.

In order to deepen our understanding of the isotopic variations recorded in women and infants in ancient populations, this study would need to be extended to other mother-infant pairs over a longer period, and should include different patterns of food diversification. Moreover, in order to shed light on all the factors, other than diet, that could influence the recording of isotopic ratios in children, research is in progress on an archaeological series of young healthy and pathological children, as well as on longitudinal tracking of animals as part of a controlled nutrition experiment.

Acknowledgements The authors are very grateful to Eärendil, Carmen, Emma and their parents, as well as to the Lei Caganis Crèche (Aix-en-Provence) for their collaboration. Milk and nail samples were provided directly by the mother. The authors also thank the anonymous reviewers for their relevant comments that improved the manuscript and Louise Byrne and Ilona Bossanyi for the English translation. The first two authors contributed equally to this paper.

Conflict of interest: None.

\section{References}

1. Herrscher E (2013) Détection isotopique des modalités d'allaitement et de sevrage à partir des ossements archéologiques. Cah Nutr Diet 48:75-85

2. Reitsema LJ (2013) Beyond diet reconstruction: stable isotope applications to human physiology, health, and nutrition. Am J Hum Biol 25:445-56 
3. Tsutaya T, Yoneda M (2015) Reconstruction of breastfeeding and weaning practices using stable isotope and trace element analyses: a review. Am J Phys Anthropol 156:2-21

4. Reynard LM, Tuross N (2015) The known, the unknown and the unknowable: weaning times from archaeological bones using nitrogen isotope ratios. J Archaeol Sci 53:618-25

5. Beaumont J, Montgomery J, Buckberry J, et al (2015) Infant mortality and isotopic complexity: new approaches to stress, maternal health, and weaning. Am J Phys Anthropol 157:441-57

6. Fogel ML, Tuross N, Owsley DW (1989) Nitrogen isotope tracers of human lactation in modern and archaeological populations. Annual Report of Geophysical Laboratory Carnegie Institution of Washington, pp 111-7

7. Schurr MR (1997) Stable nitrogen isotopes as evidence for the age of weaning at the Angel site: comparison of isotopic and demographic measures of weaning age. J Archaeol Sci 24:919-27

8. Williams JS, White CD, Longstaffe FJ (2005) Trophic level and macronutrient shift effects associated with the weaning process in the postclassic Maya. Am J Phys Anthropol 128:781-90

9. Jay A, Fuller BT, Richards MP, Knüsel CJ, et al (2008) Iron Age breastfeeding practices in Britain: Isotopic evidence from Wetwang Slack, East Yorkshire. Am J Phys Anthropol 136:327-37

10. Waters-Rist AL, Bazaliiskii VI, Weber AW, et al (2011) Infant and child diet in Neolithic hunter-fisher-gatherers from CisBaikal, Siberia: Intra-long bone stable nitrogen and carbon isotope ratios. Am J Phys Anthropol 146:225-41

11. Kaupová S, Herrscher E, Velemínský P, et al (2014) Urban and rural infant feeding practices and health in Early Medieval Central Europe (9th-10th century, Czech Republic). Am J Phys Anthropol 155:635-51

12. DeNiro MJ, Epstein S (1981) Influence of diet on the distribution of nitrogen isotopes in animals. Geochim Cosmochim Acta 45: 341-51

13. Schoeninger MJ, DeNiro MJ (1984) Nitrogen and carbon isotopic composition of bone collagen from marine and terrestrial animals. Geochim Cosmochim Acta 48:625-39

14. Bocherens H, Drucker D (2003) Trophic level isotopic enrichment of carbon and nitrogen in bone collagen: case studies from recent and ancient terrestrial ecosystems. Int J Osteol 13:46-53

15. Balter V, Simon L, Fouillet H, et al (2005) Box-modelling of ${ }^{15} \mathrm{~N} /$ ${ }^{14} \mathrm{~N}$ in mammals. Oecologia 147:212-22

16. Hedges REM, Reynard L (2007) Nitrogen isotopes and the trophic level of humans in archaeology. J Archaeol Sci 34:1240-51

17. O'Connell TC, Kneale CJ, Tasevska N, et al (2012) The dietbody offset in human nitrogen isotopic values: a controlled dietary study. Am J Phys Anthropol 149:426-34

18. Fuller BT, Fuller JL, Harris DA, Hedges REM (2006) Detection of breastfeeding and weaning in modern human infants with carbon and nitrogen stable isotope ratios. Am J Phys Anthropol 129:279-93

19. Dupras TL, Schwarcz HP, Fairgrieve SI (2001) Infant feeding and weaning practices in Roman Egypt. Am J Phys Anthropol 115:204-12

20. De Luca A, Boisseau N, Tea I, et al (2012) $\delta^{15} \mathrm{~N}$ and $\delta^{13} \mathrm{C}$ in hair from newborn infants and their mothers: a cohort study. Pediatr Res 71:598-604

21. Romek K, Julien M, Frasquet-Darrieux M, et al (2013) Human baby hair amino acid natural abundance ${ }^{15} \mathrm{~N}$-isotope values are not related to the ${ }^{15} \mathrm{~N}$-isotope values of amino acids in mother's breast milk protein. Amino Acids 45:1365-72

22. Ballard O, Morrow AL (2013) Human milk composition: nutrients and bioactive factors. Pediatr Clin North Am 60:49-74

23. Marino M, Masella R, Bulzomi P, et al (2011) Nutrition and human health from a sex-gender perspective. Mol Aspects Med 32:1-70

24. De Luca A, Tea 1, Robins RJ, et al (2013) Des cheveux pour évaluer le métabolisme protéique chez l'homme. Cah Nutr Diet 48:86-91
25. Herrscher E, De Luca A, Hankard R (2013) Rencontre entre histoire et médecine autour d'un verre d'azote-15. Cah Nutr Diet 48:308-09

26. Dumontier C (2000) L'ongle. Elsevier, Paris, 248 p

27. Runne U, Orfanos C (1981) The human nail: structure, growth and pathological changes. Curr Probl Dermatol 9:102-49

28. Ambrose SH (1993) Isotopic analysis of palaeodiets: methodological and interpretative considerations. In: Sandford M (ed) Investigations of ancient human tissue chemical analyses in anthropology. Gordon and Breach Science Publishers, Langhorne, pp 59-130

29. Beaumont J, Gledhill A, Lee-Thorp J, et al (2013) Childhood diet: a closer examination of the evidence from dental tissues using stable isotope analysis of incremental human dentine. Archaeometry 55:277-95

30. Nardoto GB, Silva S, Kendall C, et al (2006) Geographical patterns of human diet derived from stable-isotope analysis of fingernails. Am J Phys Anthropol 131:137-46

31. O'Connell TC, Hedges REM (1999) Investigations into the effect of diet on modern human hair isotopic values. Am J Phys Anthropol 108:409-25

32. O'Connell C, Hedges REM, Healey MA, et al (2001) Isotopic comparison of hair, nail and bone: Modern analyses. J Archaeol Sci 28:1247-55

33. Valentin J (2003) Basic anatomical and physiological data for use in radiological protection: Reference values, ICRP Publication 89, Ann. ICRP 32 (3-4). Elsevier, Pergamon, $280 \mathrm{p}$

34. Webb EC, Lewis J, Shain A, et al (2017) The influence of varying proportions of terrestrial and marine dietary protein on the stable carbon-isotope compositions of pig tissues from a controlled feeding experiment. STAR 3:36-52

35. Zhang Z, Adelman A, Rai D, et al (2013) Amino acid profiles in term and preterm human milk through lactation: a systematic review. Nutrients 5:4800-21

36. Mezzacappa ES (2004) Breastfeeding and maternal stress response and health. Nutr Rev 62:261-68

37. Carter CS, Altemus M (1997) Integrative functions of lactational hormones in social behavior and stress management. Ann NY Acad Sci 807:164-74

38. Purcell RH, Sun B, Pass LL, et al (2011) Maternal stress and high-fat diet effect on maternal behavior, milk composition, and pup ingestive behavior. Physiol Behav 104:474-9

39. Ambrose SH, Norr L (1993) Experimental evidence for the relationship of the carbon isotope ratios of whole diet and dietary protein to those of bone collagen and carbonate. In: Lambert JB, Grupe G (eds) Prehistoric human bone Archaeology at the molecular level. Springer, Berlin, pp 1-37

40. Herrscher E (2003) Alimentation d'une population historique. Analyse des données isotopiques de la nécropole Saint-Laurent de Grenoble ( $\mathrm{XIII}^{\mathrm{e}}-\mathrm{XV}^{\mathrm{e}}$ siècles, France). BMSAP 15:149-269

41. Szulc P, Seeman E, Delmas PD (2000) Biochemical measurements of bone turnover in children and adolescents. Osteoporosis Int 11:281-94

42. Tsutaya T, Yoneda M (2013) Quantitative reconstruction of weaning ages in archaeological human populations using bone collagen nitrogen isotope ratios and approximate Bayesian computation. PLoS One 8:e72327

43. Robbins CT, Felicetti LA, Sponheimer M (2005) The effect of dietary protein quality on nitrogen isotope discrimination in mammals and birds. Oecologia 144:534-40

44. Beaumont J, Montgomery J, Buckberry J, Jay M (2015) Infant mortality and isotopic complexity: New approaches to stress, maternal health, and weaning. Am J Phys Anthropol 157:441-57

45. Humphrey L, Dean M, Jeffries T, Penn M (2008) Unlocking evidence of early diet from tooth enamel. Proc Natl Acad Sci USA 105:6834-9 